\title{
Expressed Preference Methods of Environmental Valuation: Non-Market Resource Valuation Tools
}

\author{
Dastan Bamwesigye \\ Department of Forestry and Wood Products Economics and Policy \\ Faculty of Forestry and Wood Technology \\ Mendel University in Brno \\ Zemedelska 1, 61300 Brno \\ Czech Republic.
}

\begin{abstract}
The objective of this paper was to give an overview of the expressed preference (EP) techniques of environmental valuation. These methods offer estimation of the value of a resource not necessarily willingness to pay (WTP) or willingness to Accept (WTA) compensation rather upper and lower values. The method of measuring individuals' willingness to pay is usually based on contingent valuation method (CVM). This research focuses on defining, categorizing, and applicability of various environmental valuation techniques that have been and can be applied in attaching value to a given resource using expressed/Revealed preference methods. The study serves as a supplementary synthesis and discussion to the board of knowledge of resource valuation methods. More specifically, selected methods to discussed herein include; contingent valuation method, hedonic pricing model, travel cost method, tradeoff game method, the costless-choice method, Delphi method, Replacement Cost Method, Relocation Cost Method, Opportunity cost method, and Cost-benefit Method. In the last part, applicability of the methods is fully illustrated to support future studies on resource valuation.
\end{abstract}

\section{Keywords:}

environmental benefits and costs, revealed preference, hedonic pricing, travel cost, trade-off game, opportunity cost

\section{Introduction}

Over the past decades, the increase in production and consumption has threatened the existence of various natural resources such as forests (Bamwesigye et al. 2017, Bamwesigye and Hlavackova 2018, Bamwesigye et al. 2019). In fact, environmental planning, as well as decision making, continue to be complex in which objectives are usually exclusive, and tradeoffs have become inevitable like never before. Environmental valuation methods have been helping to facilitate the decisionmaking process regarding forests and other natural resources (Kerkhof et al., 2010; Tao et al., 2012; Perera et al., 2016). In many ways, the demand for environmental goods continues to be measured by analyzing peoples' expressed preferences for various natural resources relative to their demand for other goods and services (Kerkhof et al., 2010). Expressed preference techniques usually focus on involving individuals by asking them explicitly how much they value a wide range of environmental goods and services (Tao et al., 2012; Perera et al., 2016).
Expressed preference methods include contingent valuation method, hedonic pricing model, travel cost method, trade-off game method, the costless-choice method, Delphi method to mention but a few. Methods such as contingent valuation techniques are usually applied in the valuation of projects, which are related to environmental management such as water, energy, and waste management.

These various methods are used as tools for decision making (Kerkhof et al., 2010; Tao et al., 2012; Perera et al., 2016; Brander et al. 2007). In this case, it is always beneficial if valuation methods consider core aspects that affect certain goods and services. For example, the study conducted by (Brander et al., 2007). focused on investigating sensitivity of respondents to physical dimension of the valuable items. In other words, resources that are valued while employing expressed preference methods focus on getting feedback from the participants.

Therefore, we attempt to review some of the expressed preference (EP) methods of environmental valuation necessary for natural resources valuation since the 
understanding and comprehension of these tools still varies across the academia and society as well.

\section{Material and methods}

The study mainly used materials and data from scientific peer-reviewed journal articles and scientific conference proceedings and majority from web of Science and SCOPUS.

We employed qualitative methodology (Creswell, 2009) where we synthetically analyzed information and the data from the said sources. We studied both narratives and figures to come up with a blend of the desired output (Creswell, 2009).

The study also analyzed the data by using tables (Tables $1 \& 2$ ) to illustrate the categorization and applicability of environmental valuation methods.

\section{Findings}

\section{Contingent Valuation Method (CVM)}

The Contingent Valuation Method (CVM) is considered to be one of the widely used in cost-benefit analysis and other environmental impact assessment to provide a monetary measure of natural resources (Ryan et al., 2017). CVM helps in evaluating nonmarket assets, and this is usually done through the simulation of what can be termed a hypothetical market whereby users are asked to express their "Willingness to Pay (WTP) or Willingness to Accept (WTA) to certain goods granted in use (Del Giudice \& De Paola, 2016). More so, CVM is the best method used to explain both non-use values such as option values, existence value and bequest value (Brander et al., 2007; Del Giudice \& De Paola, 2016). On the same note, CVM approach is usually applied in the valuation of projects that are related to environmental management such as water, energy and waste management (Geleto, 2011; World Bank, 2012). For example, unlike other methods, CVM is based on information that is provided by the people themselves, and these include current as well as future affected stakeholders (Perera et al., 2016). These stakeholders are asked about the valuation of particular services or goods under investigation through markets that are hypothetical to this end.

Furthermore, CVM is based on questionnaire that aims at offering respondents' opportunity in the process of making an economic decision on certain environmental goods that are non-market such as the biodiversity, scenery, and wildlife (Geleto, 2011). Besides, World Bank indicated that CVM is important in estimating the value that people places on goods, which are not sold in markets such as environmental goods (World Bank, 2012). In this perspective, it is worth mentioning that CVM remains one of the obvious approaches that can be used to measure resource non-market values, which is done through questioning people about their willingness to pay for goods and services. In this case, the technique used is flexible, and it allows valuation of a wider variety of non-market goods compared to other indirect approaches (Venkatachalam, 2004).

\section{Trade-off game method}

Trade-off Games is considered to be part of contingent valuation method where individuals are asked to rank a combination of two goods. For any of the two combinations, an individual must select his or her preference over the other. In this case, a trade-off method is a technique that provides means that allow users to participate in decision-making process while educating them about the constraints involved in making these decisions (Howe et al., 2014). In fact, trade-off method analysis has become one of the significant approaches in evaluating different levels of environmental achievement while reflecting on the corresponding levels of costs. The trade-off game method explains win-win outcomes as well as cost offsets when it comes to estimating costs. The author gives an example of environmental watering, which may offer co-benefits such as increased net returns to floodplain graziers as a result of overbank flows (James, 2017).

More so, trade-off analysis between two environmental ecosystem services, valuation may not focus on the management options but rather empirical or conceptual models (Howe et al., 2014). Accordingly, the same study indicates that society usually influence the choice of how natural resources are sometimes allocated, and in this perspective, it makes the feature of trade-off analysis very important regardless of whether the economic value is known or not. In ecosystem or environmental services, trade-off method 
plays a significant role in helping decisionmakers by informing them about the best output an ecosystem can deliver. Trade-offs usually occur when the provision of ecosystem service is reduced due to the consequence of increased use of a different ecosystem service (Howe et al., 2014). In this case, trade-offs have always occurred among the stakeholders and among the ecosystem services, which are delivered in any location, and they can as well be influenced by social norms and life experience (Howe et al., 2014).

\section{The Costless-choice method}

In environmental/resource valuation, costless-choice is relatively similar to tradeoff game technique. However, instead of using money as one of the core elements, only marketed commodities, especially consumer goods are used in combination with other environmental attributes (James, 2013). In most cases, the monetary valuation element is usually obtained by substituting the preferred market value of chosen goods (Bateman et al., 2008). This technique relies heavily on the assumption that people understand the aspects of true market value of various goods and services. Furthermore, costless-choice method is a CVM technique that provides respondents with an option when deciding between goods based on their interests (James, 2013; Cristescu \& Szentesi, 2008). In the two available options, an individual is given a choice between non-market and economic good. One of the differences between costless choice technique and other CVM methods is that it gives individuals a choice of free of charge where an individual does not pay anything for the choice he or she chooses.

\section{Delphi Method}

Delphi method is regarded as a variant of the survey-based approach that involves experts rather than consumers. These experts place values on certain goods and services in one way or the other. For example, they can place values on goods through an iterative process, and this allows feedback among the group between iteration (Brender, 2006; Strosahl \& Robinson, 2001). The approach is very useful when valuing environmental resources. One of the characteristic features of Delphi method is that the central team usually work with a panel of experts in an iterative manner while formulating the experts' knowledge of a predefined subject under investigation (Brender, 2006). However, the same study indicates that the method includes extra steps including validating the expertise of panel members (Brender, 2006).

On the same note, Delphi method employs guideline that determines rules regarding collecting and analyzing information from experts (Strosahl \& Robinson, 2001). As a result, the opinions from experts are usually put into a set of recommendations. Delphi method is one of the formal and in-depth systematic qualitative methodologies (Strosahl \& Robinson, 2001; Dell'Olio et al., 2018; Renzi \& Freitas, 2015). The Delphi method has been used to help construct present as well as the future scenarios focused on various issues, and experts usually help in the process (Renzi \& Freitas, 2015). In most cases, this method helps in reaching a consensus between different groups of participants while basing on all posted opinions from various experiences and perspectives in order to come up with a common scenario (Renzi \& Freitas, 2015). Delphi method is one of the consensusbuilding tools that promote involvement of stakeholders in the evaluation process (Geist, 2010). The method removes geographical and other challenges to allow all stakeholders to participate. The method uses a series of surveys spread with controlled feedback that is designed to gather information while building consensus (Renzi \& Freitas, 2015; Geist, 2010).

\section{Travel cost method}

Travel cost method is an approach that indirectly values environmental goods, and this is usually done by observing willingness to pay for related goods and services. The method is used to estimate the economic value of environmental amenities as well as other recreational sites (Parsons, 2013; Markandya \& Ortiz 2011; Butterfield et al. 2016). Travel cost method is employed when studying economic use values related to ecosystems (Butterfield et al. 2016). The travel cost technique is based on the fact that the time and travel cost expenses that individuals pay to visit a site represent the price of access to the given recreation site. In this case, an individual's willingness to pay to visit various recreational sites can be estimated 
while reflecting on the number of trips people make at different travel cost.

Measuring recreational quality such as cultural services which are related to other ecosystem services can be difficult to achieve (Butterfield et al. 2016), as a result, this makes travel cost method limited in its applicability since it requires user participation. For example, it may not be used when assigning values to on-site ecosystem services, especially those that users may not find valuable in one way or the other. Travel cost method is significant in estimating the economic value as well as other expenses incurred by visitors to the site of such a resource (Markandya \& Ortiz 2011; Butterfield et al. 2016; Markandya et al. 2018). In fact, they explain that the method uses surveys to a random sample of people who visit recreational sites in order to elicit travel cost. Some of the aspects important in the process include asking visitors where they come from, preferences toward the site, their socioeconomic characteristics to mention but a few (Markandya et al. 2018). Such information is significant when it comes to estimating the cost. In this case, it is worth noting that the method assumes that each individual who visits the site incurs travel costs plus the opportunity cost of time.

Travel cost method is used to value the recreational uses of environmental goods and services including fishing, birdwatching, and beach use among others (Parsons, 2013). The method has some limitations such as measuring the value of travel and time. More so, other complexities highlighted in the same study include dealing with multiple-purpose trips as well as choice set formation (Parsons, 2013). Nonetheless, travel cost method is indicated to be useful in estimating the value of environmental goods and services.

Environmental resources such as recreation sites are measured using human activity participation, and this involves assessment of costs and benefits an individual incur when visiting recreational sites (Grebner et al., 2013). Travel cost method requires researchers to carry out surveys of visitors at the site of the activity. Also, the survey can be done through printed and or online survey questionnaires (Grebner et al., 2013).

In the study titled Ecosystem services and their monetary value, Liekens et al. (2013) highlight that travel cost method enables the researchers in estimating the economic value of environmental goods. For example, the method requires researchers to assess costs incurred by visitors traveling to various environmental resources such as recreation sites in terms of both travel and time. The aspect of travel expenses can be estimated by looking at fuel used on the journey, fares to mention but a few. On the other hand, time can be assessed by looking at foregone earnings (Liekens et al., 2013). The travel cost method technique has its limitations. For example, one of the limitations indicated is that the method is only applicable to recreational resources and difficult when it comes to accounting for the possible benefits derived from various travels as well as multipurpose trips. In this case, therefore, much as researchers may use travel cost method to estimate the value of environmental resources, it is important to consider its limitations (Parsons, 2013; Grebner et al., 2013; Liekens et al., 2013).

\section{Hedonic Pricing Model}

Research indicates that hedonic pricing method is one of the potential approaches used to determine environmental value of a given asset. In its earliest use, this technique was used to capture the aspect of willingness to pay measures related with variations in property values, which usually result from the presence or absence regarding certain environmental attributes such as near forest, near the river, air pollution, noise and water waves (Carson, 2001; Abidoye \& Chan, 2017; Burcharth et al., 2007). Hedonic pricing method is regarded as a non-market revealed preference approach with an indirect proxy that has been particularly influential (Markandya et al. 2018; Carson, 2001). On the same note, comparing the market value of different properties that differ when it comes to specific environmental attributes, researchers usually focus on assessing the implicit price of the given amenity (Abidoye \& Chan, 2017). This is done by observing the behaviour of several buyers and sellers. The variation on the technique of comparing the effect of an environmental attribute usually involves assessing the price of a single piece of property compared to successive sales (Burcharth et al., 2007). More so, the same study highlights that hedonic pricing method captures the aspect of the production function approaches, 
which relate to environmental changes to other production relationships (Burcharth et al., 2007).

Furthermore, through comparison of various factors that usually influence the value of a given property, researchers are able to eliminate the implicit price of various amenities that change from time to time. for example, the price of a house can be in one way or the other affected by various factors including square footage, number of bedrooms, schools around, highways and shopping malls to mention but a few. For example, environmental changes in production are related to companies that produce goods and services that generate utility (Burcharth et al., 2007). Based on this, hedonic pricing method focuses on the fact that changes in the expenditures are as a result of the need to substitute with other inputs in environmental quality (Burcharth et al., 2007; Nijkamp \& Van den Bergh, 2001).

Hedonic pricing methods can also be employed when estimating the effect of certain disamenities when it comes to price of property such as houses. At this point, the process of estimating a hedonic price function, which is related to property prices, and to quantities of different characteristics is always straightforward. In fact, research shows that hedonic pricing method usually helps in estimating product efficiency to identify properties that are overpriced and those under-priced (Arrondo et al., 2018). In this case, therefore, it is worth mentioning that hedonic is important in estimating values of environmental resources.

Based on the literature reviewed, the advantage of using hedonic method is that the researcher usually depends on observable data that come from the actual behavior of people. On the other hand, this technique has its limitations. For example, most environmental incidents may have small effect on property pricing. In other words, much as this technique can be used to evaluate environmental resources, its limitations cannot be ignored in one way or the other.

\section{Cost-benefit Method}

Cost-benefit is considered to be a useful form of economic evaluation. The costbenefit technique is one of the methods that provide a systematic process for identifying, valuing as well as comparing costs and benefits of environmental resources
(Knapp, 2015; Haveman \& Weimer, 2001). The method is based on the core principles of welfare economics, which considers the wellbeing of the society to be important. The method is usually employed by policymakers in the process of allocating resources across different sectors (Knapp, 2015). Cost-benefit method is important in assessing the economic efficiency of proposed public policies by using a systematic production of social costs and social benefit (Haveman \& Weimer, 2001). Just like most of the contingent valuation methods, cost-benefit has the element of willingness to pay and opportunity cost that usually guides the valuation of projects policy effects when it comes to monetary terms. More so, this method provides an appropriate decision rule as well as set of policies that maximize net social benefit (Haveman \& Weimer, 2001).

The purpose of cost-benefit method is to make better informed and at the same time consistent policy decisions (Boardman, 2015). For example, this method considers the benefits, which occur to and costs incurred by all members of the society (Boardman, 2015). The terms social benefit and social costs are derived from costbenefit approach (Boardman, 2015). In this perspective, it is worth mentioning that costbenefit method is important in evaluating environmental resources in one way or the other. Cost-benefit method helps in predicting willingness to pay while ranging from various preferences revealed by observable behavior in the market as well as the preferences about public goods.

Lastly, Cost-benefit method provides the guiding principle for monetizing impacts regarding the concept of willingness to those affected to pay in a bid to obtain or avoid the impacts (Vining \& Weimer, 2015). In a bid to understand the core aspects of cost-benefit method, it is important to explore its various methods as discussed in the next sections.

\section{Opportunity cost method}

The opportunity cost method focuses on valuing the benefits of environmental protection when it comes to what is being foregone to achieve it (Parsons, 2013; Markandya et al. 2018; Mahanta, 2014). In most cases, this method forms the basis of compensation payment, especially for the compulsory purchase driven by the government of property or land that is under 
eminent domain law (Haveman \& Weimer, 2001). More so, opportunity cost method considers that the land of property rights when it comes to using of land and natural resources to restrict the rights of the government in favor of the society, where owners must be compensated. In this case, this method is usually useful in situations where it is hard to estimate the benefits of an environmental change (Boardman, 2015). One of the examples is that, rather than assessing the benefits of various available alternative conservation schemes in a bid to choose the best option out of them, this method is usually employed to estimate the opportunity cost of foregone benefit related to each scheme compared to the selected alternative.

However, it is worth mentioning that opportunity cost method does not usually include non-market public values of property and land (Vining \& Weimer, 2015; Ahmed, 2006). One of the reasons is that land and its attributes usually produce externalities that are recognized in regulatory land use planning control. In most cases, these seek to minimize external challenges through development of control land use class order, which is also done by separating externality to allow land use spatially. More so, the planning controls focus on preserving amenity benefits, which is done through restricting the development of the land entirely (Vining \& Weimer, 2015). Nonetheless, it should be noted that by restricting land development, the price of land such as green belt land usually faces lower financial value compared to its opportunity cost value.

\section{Relocation Cost Method}

As one of the cost-benefit methods, relocation cost technique is usually employed to estimate the monetary value of environmental damages, and this is done while basing on the potential costs of relocating a physical facility, which in one way or the other would be damaged by certain environmental quality changes. Relocation cost method is relatively similar to the direct asset replacement technique only that the actual expense of physical relocating a given facility is used in the benefit-cost assessment (Rothengatter, 2018). In the context of environmental resources, relocation cost method is useful, especially in cases where relocation of a facility is necessary (Shogren, 2013). For example, the technique can be used to estimate the cost of moving a residential water supply facility that is threatened with pollution by runoff that may be caused by the new road.

\section{Replacement Cost Method}

Unlike other cost-benefit methods, this technique is cost-based approach that focuses on measuring the potential expenditure needed to replace or restore a productive asset. Such asset would be compromised by various project developments in a given area. In this case, replacement cost method is employed to compare the costs of preventing estimated damage from happening while determining alternative that is more efficient (Jackson, 2014). For example, if an environmental resource which has been compromised in one way or the other is likely to be replaced in the near future by a different asset that offers the same services, then the cost of replacement can be used as a proxy in the given environmental damage (Valero et al., 2013). In most cases, this happens when it is assumed that the benefits from former resource are at least as important as the replacement expenses. Various research have used replacement cost method while investigating quantity of the direct consumption value of sites for indigenous substance and aquatic species in Austrian tropical river catchments (Jackson, 2014). Results in their study were based on the assessed socio-economic impact of hydrological and ecological changes from water resource development.

\section{Discussion and conclusions}

The objective of this paper was to review the expressed preference methods of environmental valuation. Interestingly, a wide range of literature materials revealed that environmental valuation methods have been helping to facilitate the decisionmaking process regarding forests and other natural resources (Adamowicz et al., 1994; Colombo et al., 2006; Da Costa \& Hernandez, 2019; Mwebaze et al., 2018; Hausmann et al., 2018; Karimi \& Hockings, 2018; Barkmann et al., 2008; Frey \& Pirscher, 2019; Cerda et al., 2018). In fact, it is indicated that the demand for environmental goods continues to be measured by analyzing peoples' expressed preferences for various natural resources relative to their demand for other goods and 
services (Markandya \& Ortiz 2011; Markandya et al. 2018; Adamowicz et al. 1994; Barkmann et al., 2008; Cerda et al., 2018). While reflecting on the literature that has been reviewed for the current investigation, there are various aspects that usually influence the applicability of expressed preference methods of environmental valuation (Adamowicz et al., 1994; Colombo et al., 2006; Da Costa \& Hernandez, 2019; Mwebaze et al., 2018; Hausmann et al., 2018; Karimi \& Hockings, 2018; Barkmann et al., 2008; Frey \& Pirscher, 2019; Cerda et al., 2018). Besides, environmental resources such as forests and other public goods are considered to be different from private property since they are collectively consumed. In this case, most of the methods discussed focus on the aspect of people's willingness to pay and willingness to accept for certain goods granted in use.

Based on the literature reviewed, it is revealed that contingent valuation method is one of the best methods used to estimate the non-use values such as option values, existence value, and bequest value when it comes to forest resources. The contingent valuation method (CVM) is usually applied in the valuation of projects that are related to environmental management such as water, energy, and waste management. Besides, CVM is based on information that is provided by the people themselves, and these include current as well as future affected stakeholders (Adamowicz et al., 1994; Colombo et al., 2006; Da Costa \& Hernandez, 2019; Mwebaze et al., 2018; Hausmann et al., 2018; Karimi \& Hockings, 2018; Barkmann et al., 2008; Frey \& Pirscher, 2019; Cerda et al., 2018). Nonetheless, other methods such as tradeoff game method, costless-choice, costbased method, hedonic to mention but a few have been highlighted to be important in valuating environmental resources such as forests. On the same note, most of the valuation methods are connected to contingent valuation method in one way or the other.

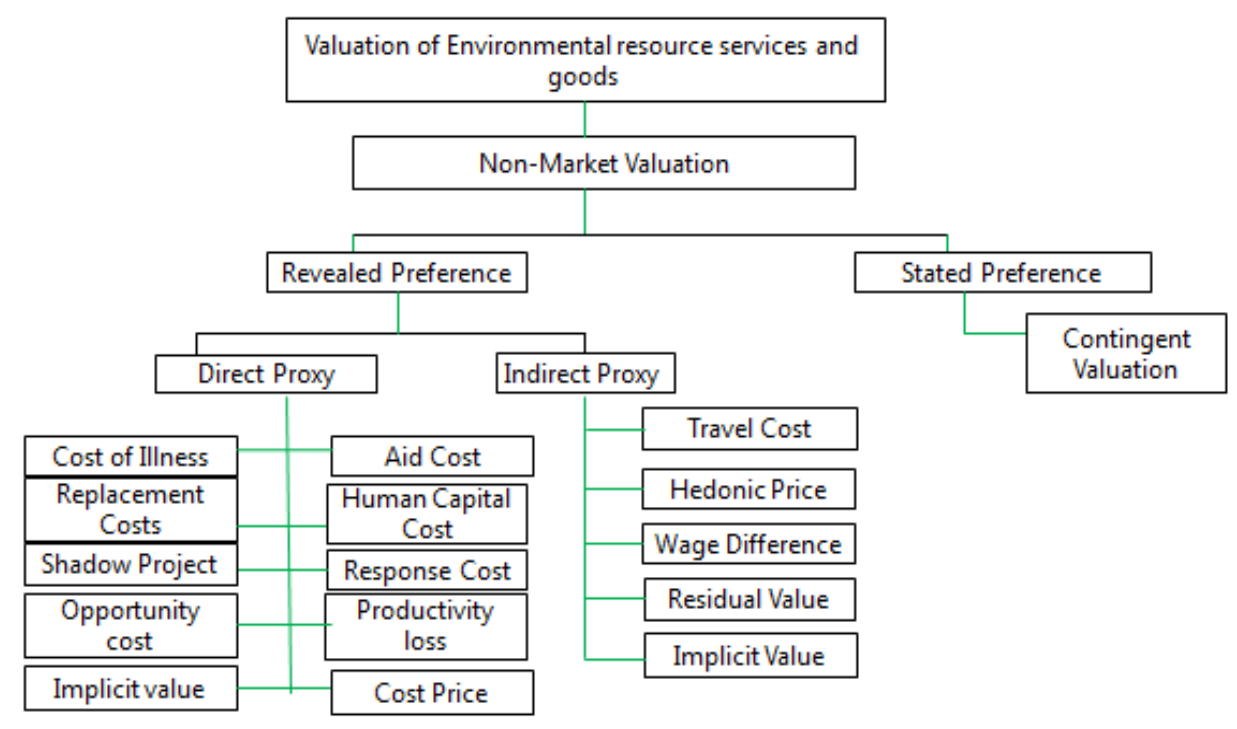

Figure 1: Possible categorization of Environmental valuation methods

Source: Own analysis based on (Markandya \& Ortiz 2011; Markandya et al. 2018; Barkmann et al., 2008; Cerda et al., 2018).

While estimating the value of environmental services, a wide range of methods explored in this review play a significant role in helping decision-makers by informing them about the best output goods and services can deliver (Markandya \& Ortiz 2011; Markandya et al. 2018;
Adamowicz et al., 1994; Da Costa \& Hernandez, 2019; Barkmann et al., 2008; Cerda et al., 2018). For example, it is indicated that hedonic pricing technique is usually used to capture the aspect of willingness to pay measures related with variations in property values that result from 
the presence or absence regarding certain environmental attributes such as air pollution, noise and water waves (Figure 1 \& Table 1).

Besides, hedonic pricing method captures the aspect of the production function approaches, which relate to environmental changes to other production relationships. Other methods such as costbenefit were found to be significant in providing a systematic process for identifying, valuing as well as comparing costs and benefits of environmental resources (Markandya \& Ortiz 2011; Markandya et al. 2018; Adamowicz et al., 1994; Da Costa \& Hernandez, 2019; Barkmann et al., 2008; Cerda et al., 2018).
Although various methods discussed use different techniques to estimate the value of environmental resources such as forests goods and services, most of them help decision makers when it comes to management of available resources. More so, the various methods explored such as contingent valuation methods, trade-off game method, costless-choice, cost-based method, hedonic to mention but a few have been employed in many investigations to estimate the value of environmental resources at both local and international level. In this case, therefore, it is worth mentioning that this review serves as the starting point to discuss environmental valuation practices while reflecting on individuals' willingness to pay for certain goods and services.

\begin{tabular}{|c|c|c|c|c|}
\hline $\begin{array}{l}\text { Environmental } \\
\text { Impact }\end{array}$ & Productivity issues & $\begin{array}{l}\text { Health } \\
\text { issues }\end{array}$ & Amenity & Existence \\
\hline Soil erosion \& fertility & $x$ & & & \\
\hline Land degradation & $\mathrm{x}$ & & $\mathrm{x}$ & $\mathrm{x}$ \\
\hline Desertification & $x$ & & & $\mathrm{x}$ \\
\hline Deforestation & $\mathrm{x}$ & & $x$ & $\mathrm{x}$ \\
\hline Loss of habitat & $x$ & & $x$ & $x$ \\
\hline Wildlife & $\mathrm{x}$ & & $\mathrm{x}$ & $\mathrm{x}$ \\
\hline Air pollution & $x$ & $x$ & $\mathrm{x}$ & \\
\hline Waste disposal & $\mathrm{x}$ & $\mathrm{x}$ & $\mathrm{x}$ & \\
\hline Water contamination & $x$ & $x$ & $x$ & \\
\hline Marine environment & $x$ & & $\mathrm{x}$ & $\mathrm{x}$ \\
\hline Overfishing & $\mathrm{x}$ & & & $\mathrm{x}$ \\
\hline Resettlement & $\mathrm{x}$ & & $\mathrm{x}$ & $x$ \\
\hline $\begin{array}{l}\text { Biodiversity, species } \\
\text { Joss }\end{array}$ & $x$ & & $x$ & $x$ \\
\hline Indigenous threat & & & & $\mathrm{x}$ \\
\hline Community disruption & $x$ & $\mathrm{x}$ & & \\
\hline Hazardous waste & $x$ & $x$ & $x$ & \\
\hline $\begin{array}{ll}\text { Surface } & \text { water } \\
\text { pollution } & \end{array}$ & $x$ & $x$ & & $\mathrm{x}$ \\
\hline Method of Valuation & $\begin{array}{l}\text { Productivity change } \\
\text { Response cost } \\
\text { Substitution cost } \\
\text { Shadow project } \\
\text { Replacement cost }\end{array}$ & $\begin{array}{l}\text { Response } \\
\text { cost } \\
\text { Human } \\
\text { Capital cost } \\
\text { Cost of } \\
\text { illness }\end{array}$ & $\begin{array}{l}\text { Hedonic } \\
\text { Pricing } \\
\text { CVM } \\
\text { Travel Cost }\end{array}$ & $\begin{array}{l}\text { Contingent } \\
\text { Valuation Method } \\
\text { (CVM) }\end{array}$ \\
\hline
\end{tabular}

Table 2: Applicability of Environmental valuation methods

Source: Own analysis based on (Kerkhof et al. 2010; Howe et al., 2014; Markandya \& Ortiz, 2011; Markandya et al. 2018; Cerda et al., 2018)

The investigation concludes with the classification of revealed methods and expounding on their categories as well as their applicability in the estimation of the value of a given resource (Figure 1 \& Table 1). Although not fully discussed here in, in 
Figure 1, we also illustrated where Stated Preference (SP) is applicable. For example, The study shows that Contingent Valuation Method (CVM) is the best applicable tool when we are interested in the stated preference (Markandya \& Ortiz 2011; Markandya et al. 2018; Barkmann et al., 2008). The study also illustrates which resources and their possible technique that can used in the estimating the value of such an environmental good (Table 1).

\section{References}

Abidoye, R. B., \& Chan, A. P. (2017). Critical review of hedonic pricing model application in property price appraisal: A case of Nigeria. International Journal of Sustainable Built Environment, 6(1), 250259. doi:10.1016/j.ijsbe.2017.02.007

Adamowicz, W., Louviere, J., \& Williams, M. (1994). Combining revealed and stated preference methods for valuing environmental amenities. Journal of environmental economics and management, 26(3), 271-292.

Ahmed, S. (2006). Contingent Valuation Method. Cost-Benefit Analysis of Environmental Goods by Applying the Contingent Valuation Method, 11-17. doi:10.1007/4-431-28950-x_2

Arrondo, R., Garcia, N., \& Gonzalez, E. (2018). Estimating product efficiency through a hedonic pricing best practice frontier. $B R Q \quad$ Business Research Quarterly, 21(4), 215-224. doi:10.1016/j.brq.2018.08.005

Bamwesigye, D., Akwari, N. F., Hlavackova, P. 2019. Forest Product Export Performance in Tropical Africa: An Empirical Analysis of the Forest Sector. Forum Scientiae Oeconomia, 7 (1), 73--83. ISSN 2300-5947

Bamwesigye, D., Darkwah, S. A., Hlavackova, P., Kupcak, V. 2017. Firewood and Charcoal Production in Uganda. 17th International Multidisciplinary Scientific GeoConference SGEM 2017, www.sgemviennagreen.org, SGEM2017 Vienna GREEN Conference Proceedings, Vol. 17, Issue 33, 521-528 pp; DOI: 10.5593/sgem2017H/33/S14.065

Bamwesigye, D., Hlavackova, P. 2018. Forest wood production in Tropical Africa. Journal of Landscape Management 9(1), 39-45.

Barkmann, J., Glenk, K., Keil, A., Leemhuis, C., Dietrich, N., Gerold, G., \&
Marggraf, R. (2008). Confronting unfamiliarity with ecosystem functions: the case for an ecosystem service approach to environmental valuation with stated preference methods. Ecological economics, 65(1), 48-62.

Bateman, I. J., Munro, A., \& Poe, G. L. (2008). Decoy Effects in Choice Experiments and Contingent Valuation: Asymmetric Dominance. Land Economics, 84(1), 115-127. doi:10.3368/le.84.1.115

Boardman, A. E. (2015). Cost-Benefit Analysis. International Encyclopedia of the Social \& Behavioral Sciences, 47-54. doi:10.1016/b978-0-08-097086-8.71068-3

Brander, L. M., Van Beukering, P., \& Cesar, H. S. (2007). The recreational value of coral reefs: A meta-analysis. Ecological Economics, 63(1), 209-218. doi:10.1016/j.ecolecon.2006.11.002

Brender, J.

(2006). Introduction. Handbook of Evaluation Methods for Health Informatics, 3-8. doi:10.1016/b978-012370464-1.50001-0

Burcharth, H. F., Hawkins, S. J., Zanuttigh, B., \& Lamberti, A. (2007). Design tools related to engineering. Environmental Design Guidelines for Low Crested Coastal Structures, 203-333. doi:10.1016/b978008044951-7/50033-6

Butterfield, B. J.,

Camhi, A. L., Rubin, R. L., \& Schwalm, C. R. (2016). Tradeoffs and Compatibilities among Ecosystem Services. Ecosystem Services: From Biodiversity to Society, Part 2, 207243. doi:10.1016/bs.aecr.2015.09.002

Carson, R. (2001). Resources and Environment: Contingent Valuation. International Encyclopedia of the Social \& Behavioral Sciences, 1327213275. doi:10.1016/b0-08-043076-7/041966

Cerda, C., Fuentes, J. P., \& Mancilla, G. (2018). Can conservation in protected areas and visitor preferences converge? An empirical study in Central Chile. Biodiversity and conservation, 27(6), 1431-1451.

Colombo, S., Calatrava-Requena, J., \& Hanley, N. (2006). Analysing the social benefits of soil conservation measures using stated preference methods. Ecological Economics, 58(4), 850-861.

Creswell, J. W. (2009). Research Design: Qualitative, Quantitative, and Mixed Methods Approaches (3rd ed.). Thousand Oaks, CA: Sage. 
Cristescu, G., \& Szentesi, S. G. (2008). Environmental Valuation Techniques. Fascicle of Management and Technological Engineering, 7(17).

Da Costa, P., \& Hernandez, D. (2019). The Economic Value of Ecosystem Conservation: A Discrete Choice Experiment at the Taravo River Basin in Corsica.

Del Giudice, V., \& De Paola, P. (2016). The Contingent Valuation Method for evaluating historical and cultural ruined properties. Procedia-Social and Behavioral Science, 595-600.

Dell'Olio, L., Ibeas, A., Oña, J. D., \& Oña, R. D. (2018). How to Study Perceived Quality in Public Transport. Public Transportation Quality of Service, 7-32. doi:10.1016/b978-0-08-102080-7.00002-1

Frey, U. J., \& Pirscher, F. (2019). Distinguishing protest responses in contingent valuation: A conceptualization of motivations and attitudes behind them. PloS one, 14(1), e0209872.

Geist, M. R. (2010). Using the Delphi method to engage stakeholders: A comparison of two studies. Evaluation and Program Planning, 33(2), 147-154. doi:10.1016/j.evalprogplan.2009.06.006

Geleto, A. K. (2011). Contingent valuation technique: A review of literature. ISABB Journal of Health and Environmental Sciences, 1(1), 8-16. Retrieved from DOI: 10.5897/ISAABJHE11.017

Grebner, D. L., Bettinger, P., \& Siry, J. P. (2013). Ethics. Introduction to Forestry and Natural Resources, 407-425. doi:10.1016/b978-0-12-386901-2.00017-8

Hausmann, A., Toivonen, T., Slotow, R., Tenkanen, H., Moilanen, A., Heikinheimo, V., \& Di Minin, E. (2018). Social media data can be used to understand tourists' preferences for nature-based experiences in protected areas. Conservation Letters, 11(1), e12343.

Haveman, R., \& Weimer, D. (2001). Cost-Benefit Analysis. International Encyclopedia of the Social \& Behavioral Sciences, 2845-2851. doi:10.1016/b0-08043076-7/02239-7

Howe, C., Suich, H., Vira, B., \& Mace, G. M. (2014). Creating win-wins from trade-offs? Ecosystem services for human well-being: A meta-analysis of ecosystem service trade-offs and synergies in the real world. Global Environmental Change, 28,
263-275.

doi:10.1016/j.gloenvcha.2014.07.005

Jackson, S., Finn, M., \& Scheepers, K. (2014). The use of replacement cost method to assess and manage the impacts of water resource development on Australian indigenous customary economies. Journal of Environmental Management, 135, 100-109. doi:10.1016/j.jenvman.2014.01.018

James, D. (2017). The Role of Economic Analysis in Water Resource ManagementThe Murray-Darling Experience. Decision Making in Water Resources Policy and Management, 133-149. doi:10.1016/b9780-12-810523-8.00009-4

James, D. E. (2013). The Application of Economic Techniques in Environmental Impact Assessment. Berlin, Germany: Springer Science \& Business Media.

Karimi, A., \& Hockings, M. (2018). A social-ecological approach to land-use conflict to inform regional and conservation planning and management. Landscape ecology, 1-20.

Kerkhof, $A$.

Drissen, E., Uiterkamp, A. S., \& Moll, H. (2010). Valuation of environmental public goods and services at different spatial scales: a review. Journal of Integrative Environmental Sciences, 7(2), 125-133. doi:10.1080/19438151003709832

Knapp, M. (2015). Psychiatric Care, Economics of. International Encyclopedia of the Social \& Behavioral Sciences, 295-300. doi:10.1016/b978-0-08-097086-8.27053-0

Liekens, I., De Nocker, L., Broekx, S., Aertsens, J., \& Markandya, A. (2013). Ecosystem Services and Their Monetary Value. Ecosystem Services, 13-28. doi:10.1016/b978-0-12-419964-4.00002-0

Mahanta, R. (2014). Opportunity Cost of Biodiversity Conservation and Attitudes Towards it in Assam. Environment and Natural Resources Research, 4(3). doi:10.5539/enrr.v4n3p83

Markandya, A., \& Ortiz, R. (2011). General Introduction to Valuation of Human Health Risks. Encyclopedia of Environmental Health, 871-878. doi:10.1016/b978-0-444-52272-6.00302-0 Markandya, A., Ortiz, R. A., \& Chiabai, A. (2018). Estimating Environmental Health Costs: General Introduction to Valuation of Human Health Risks. Reference Module in Earth Systems and Environmental Sciences. doi:10.1016/b978-0-12-409548-9.10657-8 
Mwebaze, P., Marris, G. C., Brown, M., MacLeod, A., Jones, G., \& Budge, G. E. (2018). Measuring public perception and preferences for ecosystem services: A case study of bee pollination in the UK. Land use policy, 71, 355-362.

Ndimele, P. E., Akanni, A., Shittu, J. A., Ewenla, L. O., \& Ige, O. E. (2018). Tradeoff Analyses of Ecosystem Services in Nigerian Waters. The Political Ecology of Oil and Gas Activities in the Nigerian Aquatic Ecosystem, 229-256. doi:10.1016/b978-0-12-809399-3.00016-1

Nijkamp, P., \& Van den Bergh, J. (2001). Environmental and Resource Management. International Encyclopedia of the Social \& Behavioral Sciences, 45804585. doi:10.1016/b0-08-043076-7/04139-5

Parsons, G. (2013). Travel Cost Methods. Encyclopedia of Energy, Natural Resource, and Environmental Economics, 349-358. doi:10.1016/b978-0-12-3750679.00002-4

Perera, A. G., Vivas, S. G., \& Zamora, M. D. (2016). Valuing environmental management practices through contingent valuation. A review of recent applications. International Journal of Sustainable Society, 8(1), 22. doi:10.1504/ijssoc.2016.074949

Renzi, A. B., \& Freitas, S. (2015). The Delphi Method for Future Scenarios Construction. Procedia Manufacturing, 3, 5785-5791.

doi:10.1016/j.promfg.2015.07.826

Rothengatter, W. (2018). Economic Valuation of Health Impacts in Cost-Benefit Analyses of Transport Infrastructure Projects in Europe. Reference Module in Earth Systems and Environmental Sciences. doi:10.1016/b978-0-12-4095489.10650-5

Ryan, M., Mentzakis, E., Jareinpituk, S., \& Cairns, J. (2017). External Validity of Contingent Valuation: Comparing Hypothetical and Actual Payments. Health Economics, 26(11), doi:10.1002/hec.3436

Shogren, J. F. (2013). Preface. Encyclopedia of Energy, Natural Resource, and Environmental Economics, xxiii. doi:10.1016/b978-0-12-3750679.09979-4

Strosahl, K., \& Robinson, P. (2001). Psychotherapy: Clinical Practice Guidelines. International Encyclopedia of the Social \& Behavioral Sciences, 12476-
12480. doi:10.1016/b0-08-043076-7/013255

Tao, Z., Yan, H., \& Zhan, J. (2012). Economic Valuation of Forest Ecosystem Services in Heshui Watershed using Contingent Valuation Method. Procedia Environmental Sciences, 13, 2445-2450. doi:10.1016/j.proenv.2012.01.233

Valero, A., Valero, A., \& Domínguez, A. (2013). Exergy Replacement Cost of Mineral Resources. Journal of Environmental Accounting and Management, 1(2), 147-158. doi:10.5890/jeam.2013.05.004

Venkatachalam, L. R. (2004). The contingent valuation method: a review. Environmental Impact Assessment Review, 24(1), 89-124. doi:10.1016/s01959255(03)00138-0

Vining, A. R., \& Weimer, D. L. (2015). Policy Analysis. International Encyclopedia of the Social \& Behavioral Sciences, 273$280 . \quad$ doi:10.1016/b978-0-08-0970868.10555-0

World Bank. (2012). Poverty Reduction and Economic Management Network Economic Policy and Debt Department. Policy Research Working Paper http://documents.worldbank.org/curated/en/ 426771468340167345/pdf/WPS6131.pdf

\author{
Contact \\ Ing. Dastan Bamwesigye \\ Mendel University in Brno \\ Zemedelska 1, 61300 Brno or \\ Jana Babka 3, 61600 Brno \\ Mobile: +420776332898 \\ E-mail: xbamwesi@mendelu.cz
}

